\title{
Ameliorative Effect of the Oral Administration of Chuquiraga spinosa in a Murine Model of Breast Cancer Induced with 7,12-Dimethylbenz[a]anthracene (DMBA)
}

\author{
Jorge Luis Arroyo-Acevedo', Oscar Herrera-Calderon 2,*, Johnny Aldo Tinco-Jayo ${ }^{3}$, Juan Pedro Rojas-Armas ${ }^{1}$, \\ Abdur Rauf ${ }^{4}$, Renán Hañari-Quispe ${ }^{5}$, Linder Figueroa-Salvador ${ }^{6}$, Victor Fernández-Guzmán7, Ricardo Ángel \\ Yuli-Posadas $^{8}$
}

Jorge Luis Arroyo-Acevedo', Oscar Herrera-Calderon ${ }^{2, *}$, Johnny Aldo Tinco-Jayo ${ }^{3}$, Juan Pedro RojasArmas', Abdur Rauf ${ }^{4}$, Renán Hañari-Quispe ${ }^{5}$, Linder FigueroaSalvador ${ }^{6}$, Victor FernándezGuzmán ${ }^{7}$, Ricardo Ángel YuliPosadas $^{8}$

'Laboratory of Experimental Pharmacology, Faculty of Medicine, Universidad Nacional Mayor de San Marcos, Lima, PERU.

${ }^{2}$ Academic Department of Pharmacology, Bromatology and Toxicology, Faculty of Pharmacy and Biochemistry, Universidad Nacional Mayor de San Marcos, Lima, PERU. ${ }^{3}$ Academic Department of Human Medicine, School of Pharmacy and Biochemistry, Universidad Nacional San Cristóbal de Huamanga, Ayacucho, PERU.

${ }^{4}$ Department of Chemistry, University of Swabi, Swabi-23430, KPK, PAKISTAN. ${ }^{5}$ Department of Clinic Pathology, Faculty of Veterinary medicine and Zootechnics, Universidad Nacional del Altiplano, Puno, PERU.

${ }^{6}$ School of Medicine, Universidad Peruana de Ciencias Aplicadas, Lima, PERU. ${ }^{7}$ Graduate School of Business, ESAN University, Lima, PERU.

${ }^{8}$ Universidad Continental, Huancayo, PERU.

\section{Correspondence}

\section{Dr. Oscar Herrera Calderon}

Jr Puno 1002, Cercado de Lima, Faculty of Pharmacy and Biochemistry, Universidad Nacional Mayor de San Marcos, Lima, PERU.

E-mail: oherreraca@unmsm.edu.pe, oherreracalderon@gmail.com

History

- Submission Date: $12-02-2020$

- Review completed: 25-02-2020;

- Accepted Date: 05-03-2020

DOI : 10.5530/pj.2020.12.85

Article Available online http://www.phcogj.com/v12/i3

Copyright

(C) 2020 Phcogj.Com. This is an openaccess article distributed under the term of the Creative Commons Attribution 4.0 International license.

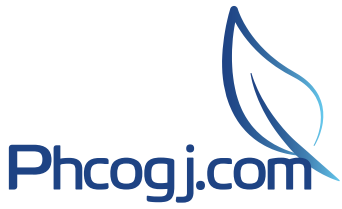

ABSTRACT

Objective: To determine the ameliorative effect of the ethanolic extract of Chuquiraga spinosa (ChS) on 7,12-Dimethylbenz[a]anthracene (DMBA)-induced breast cancer in rats. Methods: 36 female Holztman rats were divided into 6 groups. 1) The negative control group received physiological saline (PS). II) ChS-200 group received $200 \mathrm{mg} / \mathrm{kg}$ of ChS. III) DMBA group was induced with DMBA $(20 \mathrm{mg} / \mathrm{Kg})$ dissolved in PS and administrated orally for 15 weeks. IV) DMBA + ChS-50 group, V) DMBA + ChS-250 group, and VI) DMBA + ChS-500 group, which received the extract orally for 15 weeks after DMBA induction. All data were expressed as mean and standard deviation. One-way analysis of variance (ANOVA) followed by Dunnet test was carried out to compare the mean value of different groups Histopathological analysis was evaluated by using Image J software. Results: Hematology showed that the triglyceride level was significantly lowered $(P<0.01)$ and high-density lipoprotein $(H D L)$ level was significantly increased $(P<0.01)$ in groups III, IV and V. Also, ChS extract significantly lowered the $\mathrm{C}$ reactive protein $(C R P)$ level $(P<0.01)$ and malondialdehyde level $(P<0.05)$. There was a significant decrease in the frequency of DMBA-induced micronucleated polychromatic erythrocyte $(P<0.01)$. Conclusions: Chuquiraga spinosa showed an ameliorative effect on DMBA-induced breast cancer in rats as well as antioxidant, antitumor and antigenotoxic properties.

Key words: Breast tumor, Preventive medicine, Phytochemical, Antioxidant, Toxicity, Anticarcinogenic agent

\section{INTRODUCTION}

Breast cancer is the second most common cancer in the world and in women, with an estimated 1.67 million new cancer cases diagnosed in 2012 (25\% of all cancers). In Peru, this cancer represents the second most frequent neoplasm, affects the adult woman and is an important cause of disease burden. ${ }^{1,2}$ It has genetic, environmental, and lifestyle factors interacting to cause this disease. ${ }^{3}$ Breast cancer is treated by surgery, chemotherapy, radiotherapy, alone or combined depending on the severity. ${ }^{4}$ The number of deaths from cancer is increasing in developing countries due to the adoption of life styles of developed countries. ${ }^{5,6}$ Epidemiological and experimental studies indicate that high consumption of vegetables helps to lower risk of breast cancer. ${ }^{7}$

The inflammation plays an important role in tumorigenesis and polyphenols have a high antioxidant activity, which has been related to inflammatory activities. ${ }^{8}$ Chuquiraga spinosa $(\mathrm{ChS})$ is a medicinal plant used in Yauyos (JuninPeru). It belongs to the Asteraceae family and has a high content of flavonoids, tannins, alkaloids, terpenes and other phenolic compounds. ${ }^{9}$ It is used as diuretic, anti-inflammatory, renal debugger and prostate cancer. ${ }^{10}$ The present study aimed to determine the antitumor, antioxidant and antigenotoxic effect of the ethanolic extract of the aerial parts of ChS on DMBA-induced breast cancer in a murine model.

\section{MATERIALS AND METHODS}

\section{Chemicals}

7,12-Dimethylbenz[a]anthracene (DMBA), Folin Ciocalteu reagent (FCR), gallic acid standard, minimal essential medium, fetal bovine serum, Dulbecco's modified Eagle's medium, dimethyl sulfoxide (DMSO), sulforhodamine B (SRB) and 5-flurouracil were obtained from Sigma Chemical Co. Kits for hematology and biochemical test were purchased from Quimica Suiza S.A. Other reagents were of chemical grade for analysis.

\section{Cell lines}

The cell lines MCF-7 (cancer) and 3T3 (mouse embryonic fibroblasts) were purchased from the American Type Culture Collection (ATCC, Manassas, VA, USA).
Cite this article: Arroyo-Acevedo J, Herrera-Calderon O, Tinco-Jayo JA, Rojas-Armas JP, Rauf A, Hañari-Quispe R, et al. Ameliorative Effect of the Oral Administration of Chuquiraga Spinosa in a Murine Model of Breast Cancer Induced with 7,12-Dimethylbenz[a]anthracene (DMBA) Pharmacogn J. 2020;12(3):562-8. 


\section{Preparation of the extract}

Chuquiraga spinosa Lessing was collected in Huancayo, Junín, Peru. Taxonomic identification of the plant was carried out at the Museum of Natural History of Lima, Peru. The aerial parts were selected from the intact plants and dried at $40^{\circ} \mathrm{C}$. Next, it was macerated with $96 \%$ ethanol and evaporated at $40^{\circ} \mathrm{C}$. The resulting dry residue was kept in amber bottles at $5^{\circ} \mathrm{C}$ in darkness for later reconstitution.

\section{Qualitative phytochemical screening}

\section{Determination of alkaloids}

Dragendorff' $s$ test: Dragendorff reagent was added to the extract. The presence of alkaloid was indicated by the formation of a reddish-brown precipitate. $^{11}$

Mayer's test: Mayer's reagent was added to extract solution. The presence of alkaloid was indicated by the formation of a creamy white precipitate. $^{11}$

\section{Determination of anthraquinones}

Bornträger test: A small quantity of chloroform and $\mathrm{NH}_{4} \mathrm{OH}$ drops were mixed with a small amount of the extract. The presence of anthraquinone derivatives was indicated by the formation of pink, red, or violet color. ${ }^{11}$

\section{Determination of flavonoids}

Shinoda's test: $\mathrm{HCl}$ drops and magnesium were added and mixed with the extract. The presence of flavonoids was indicated by the formation of red color.

\section{Determination of phenols}

Ferric chloride test: $\mathrm{FeCl}_{3}$ was added in drops to the extract. The presence of tannin compounds was indicated by the appearance of blue-green color in the solution. ${ }^{11}$

\section{Determination of saponins}

Frothing test: The powdered extract and water were vigorously shaken in a test tube. The presence of saponins was indicated by the frothing. ${ }^{11}$

\section{Determination of steroids and terpenes}

Liebermann- Burchard's test: $2 \mathrm{~mL}$ of acetic anhydrous was added to $0.2 \mathrm{gr}$ of the extract and the solution was cooled while $\mathrm{H}_{2} \mathrm{SO}_{4}$ was added carefully. The presence of steroids and terpenes was indicated by the color change from violet to blue or bluish-green. ${ }^{11}$

\section{Determination of tannins}

Gelatin test: A $1 \%$ gelatin solution containing $10 \%$ sodium chloride was added to each leaf and bark (mixture) extract. The presence of tannins and phenolic compounds was indicated by the formation of a with precipitate. $^{12}$

\section{Quantitative phenolic analysis}

The phytochemical screening of the ethanolic extract was carried out in the facilities of the Laboratory of Experimental Pharmacology of the Faculty of Medicine (Universidad Nacional Mayor de San Marcos). The determination of phenolic compounds was done using the FolinCiocalteu method. ${ }^{13}$

\section{Animals}

Thirty-six female Holztman rats were purchased from the National Institute of Health of Peru. The animals were maintained in a temperature-controlled room with alternating $12 \mathrm{~h}$ light/12 h dark cycles in an animal facility at the Universidad Nacional Mayor de San
Marcos. Animals were fed standard rat chow and allowed free access to water. After a preconditioning period of 7 days, the experiment began. Rats were weighted and palpated to detect any mammary tumors every week.

\section{Tumor induction}

Tumor induction was performed by an intraperitoneal injection of 20 $\mathrm{mg} / \mathrm{Kg}$ of DMBA. This method was developed by Barroso et al. and Arroyo et al. ${ }^{14,15}$ All groups received tumor induction, except PS and ChS200 groups.

\section{Experimental design}

Thirty-six female Holztman rats were divided into 6 groups. The negative group, PS, received $2 \mathrm{~mL} / \mathrm{kg}$ of physiological saline orally for 15 weeks. Group ChS 200 received $200 \mathrm{mg} / \mathrm{kg}$ body weight of ethanolic extract of Chuquiraga spinosa orally as drug control for 15 weeks. Experimental groups were induced with DMBA on the first day and received $2 \mathrm{~mL} / \mathrm{kg}$ of physiological saline orally for 15 weeks. The groups DMBA + ChS50, DMBA + ChS250, and DMBA + ChS500 received ethanolic extract of Chuquiraga spinosa (50, 250, and $500 \mathrm{mg} / \mathrm{kg}$ body weight, respectively) orally for 15 weeks after DMBA induction.

Animals were sacrificed with pentobarbital (100 mg/kg). Blood samples were obtained to assess the biochemical parameters, hematological indicators, and nuclear abnormalities. Breast, Kidneys, liver, heart, and lungs were removed and carefully examined. The organs were fixed in $10 \%$ phosphate-buffered formalin and stained with hematoxylin and eosin (H\&E).

\section{Micronucleus test}

The antigenotoxic effect was determined by the frequency of micronucleated polychromatic erythrocytes (MNPCE) proposed by Hayashi. ${ }^{16}$ Peripheral blood was obtained to prepare a blood film. They were fixed with methanol and stained with $3 \%$ Giemsa. The frequency of MNPCE in 1000 polychromatic erythrocytes (PCE) per animal, was recorded.

\section{Biochemical parameters}

SOD was assayed reduction of nitroblue tetrazolium (NBT) to waterinsoluble blue formazan. This method was described by Beauchamp and Fridovich. According to the method of Begue and Aust, lipid peroxidation was detected by the determination of MDA production Biochemistry VITROS and Integrated system VITROS 5600 were used to determine the levels of C-Reactive Protein (CRP). ${ }^{17,18}$

Hematological parameters. Spectrophotometry (B-hemoglobin, Hemocue) was used to determine the hemoglobin level. Centrifuged arterial blood was taken in heparinized capillary tubes to measure hematocrit. A Neubauer chamber was used to measure the total leukocyte count. A commercial enzymatic kit (Wiener Lab, Argentina) was used to determine the blood glucose. The modified Schonewille's method estimated the total cholesterol level. ${ }^{19}$ The HDL-cholesterol level was determined with the method of Ajiboye. ${ }^{20}$ The level of triglycerides was estimated according to Deori method. ${ }^{21}$ Mohun and Cook methods were used to determine the Alanine aminotransferase (ALT) level. ${ }^{22}$ The method of Talageri et al..$^{23}$ was used to assess the Alkaline phosphatase (ALP) activity. The cleavage of urea with urease (Berthelot's reaction) was used to determinate Urea according to Liu et al. ${ }^{24}$

\section{Cytotoxicity assay in MCF-7 cell line}

This in vitro-test was developed on tumor cell line of breast cancer (MCF-7), and 3T3 (mouse embryonic fibroblast) was used as control normal cells. Cells were maintained at $37^{\circ} \mathrm{C}$ in a $5 \% \mathrm{CO}_{2}$ atmosphere. MCF-7 cell line was grown in minimal essential medium in the presence 
of $10 \%$ fetal bovine serum and $50 \mu \mathrm{g} / \mathrm{mL}$ gentamicin as antibiotic to avoid any microbial contamination. 3T3 cells were grown in Dulbecco's modified Eagle's medium. Next, both cell lines were washed in $3 \times 4$ $\mathrm{mL}$ Hank's balanced salt solution. Subsequently, $1 \mathrm{~mL}$ trypsin/EDTA was added and 10 minutes later, it was washed. The cell cultures were incubated for 8 minutes at $37^{\circ} \mathrm{C}$ and each culture was resuspended in 2 $\mathrm{mL}$ medium. Then, cells were counted using a hemocytometer.

Extract and 5-FU was diluted in dimethyl sulfoxide (DMSO) and centrifuged at $13,500 \mathrm{~g}$ for 10 minutes. The initial concentration used was $250 \mathrm{ug} / \mathrm{mL}$ for $5-\mathrm{FU}$ and $250 \mathrm{ug} / \mathrm{mL}$ for extract. Plates were incubated for 48 additional hours. To evaluate antitumor activity, cytotoxicity bioassay method with sulforhodamine B (SRB) was performed as described by Skehan et al. ${ }^{25}$ The $50 \%$ inhibitory concentration $\left(\mathrm{IC}_{50}\right)$ was found by linear regression analysis. The extract selectivity index was defined as the ratio of cytotoxicity between $3 \mathrm{~T} 3$ cell line and MCF7 cells, which was $>1$ when the cytotoxicity for tumor cells was greater than in normal cells.

Statistical analysis. Data was expressed \pm standard deviation (SD). Data were analyzed for homogeneity of variance and normality by the Levene and Wilk-Shapiro tests. One-way analysis of variance (ANOVA) followed by Dunnett's test was carried out to compare the mean value of different groups. A P-value of $<0.05$ was considered statistically significant in all cases. SPSS v. 20 was used to analyze the data.

Ethical considerations. The protocol was approved by the Institute for Ethics in Health of Universidad Nacional Mayor de San Marcos (00531-R-15-UNMSM). Ethical principles for research were respected and the rats were euthanized according to Recommendations for Euthanasia of Experimental Animals of the European Commission. ${ }^{26}$

\section{RESULTS}

Table 1 shows the phytochemical analysis of the ethanolic extract of Chuquiraga spinosa aerial parts. In the quantitative analysis of total phenolic compounds, the extract has $20.4 \pm 1 \mathrm{mg} \mathrm{GAE} / \mathrm{g}$.

The results also showed that groups treated with 50,250, and $500 \mathrm{mg} /$ $\mathrm{kg}$ body weight extract had an increased body weight. A significant increase in body weight was found in ChS500 + DMBA group (230.00 \pm 20 g; $P<0.01$; compared with DMBA group). ChS50 + DMBA and ChS250 + DMBA groups also were effective during the experiment and presented significant values $(218.00 \pm 10 \mathrm{~g}, P<0.05 ; 225.20 \pm 15 \mathrm{~g} ; P<0.01$, respectively) compared with DMBA group (Figure 1).

The hematological and biochemical analysis (Table 2) showed that there was no significant difference in the hemoglobin, hematocrit, cholesterol and urea levels. However, a significant reduction in the white blood cell count was observed, with a dose-dependent effect in the groups treated with ChS. Likewise, in group ChS 200, there was an increase in HDL levels and alkaline phosphatase levels. As well as a significant decrease in triglyceride levels, glucose, creatinine and transaminases. The same was observed in groups DMBA + ChS50, DMBA + ChS250, and DMBA + ChS500.

The antitumor and antigenotoxic effect of the ethanolic extract is dose-dependent. We observed significantly reduction in the mass of tumors and micronuclei in the groups treated with Chuquiraga spinosa compared with DMBA group (Table 3). The antioxidant activity in vivo as well as oxidative stress markers indicate significantly increased CRP (Figure 2) levels in DMBA group compared to the groups treated with the extract $(p<0.05)$. SOD activity was significantly elevated in groups treated with ChS compared to group DMBA (Figure 3).

Table 1: Phytochemical constituents of the ethanolic extract of Chuquiraga spinosa aerial parts.

\begin{tabular}{ccc}
\hline Constituents & Test & Result \\
\hline & Mayer & + \\
Alkaloids & Dragendorff & + \\
& Wagner & + \\
Flavonoid & Shinoda & + \\
Quinone & Bornträger & - \\
Phenols compounds & Ferric chloride & + \\
Saponins & frothing & - \\
Tannins & Gelatin & + \\
Terpenes and steroids & Liebermann-Burchard &
\end{tabular}

Notes: (+) positive, (-) negative.

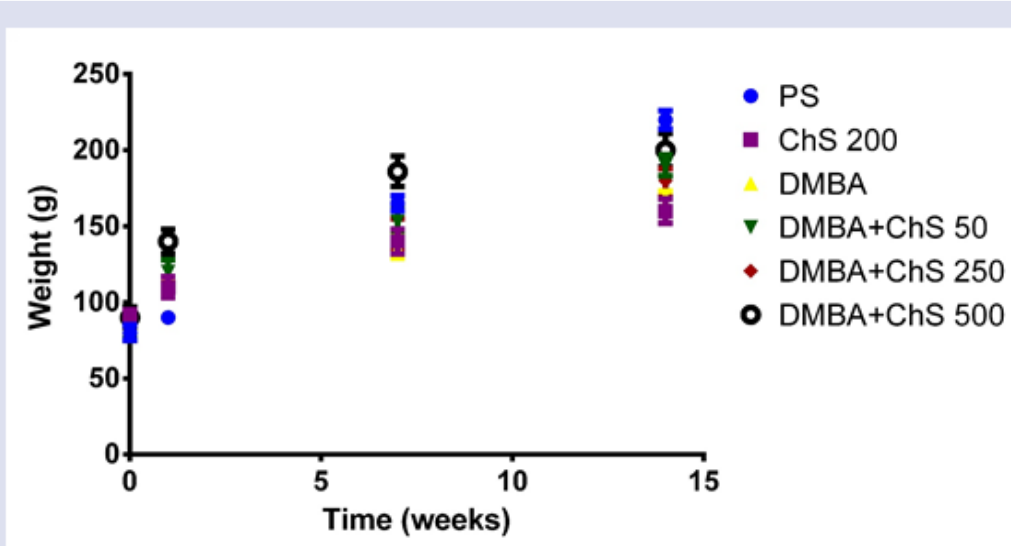

Figure 1: Effect of ethanolic extract of Chuquiraga spinosa on body weight on DMBA induced cancer in rats. 
Arroyo-Acevedo, et al:: Ameliorative Effect of the Oral Administration of Chuquiraga spinosa in a Murine Model of Breast Cancer Induced with 7,12-Dimethylbenz[a] anthracene (DMBA)

Table 2: Hematological and biochemical parameters in female rats with breast cancer induced with DMBA.

\begin{tabular}{|c|c|c|c|c|c|c|c|c|c|c|c|}
\hline \multirow[b]{2}{*}{$\begin{array}{l}\text { Experimental } \\
\text { Group }\end{array}$} & \multicolumn{5}{|c|}{ Hematological } & \multicolumn{5}{|c|}{ Biochemical } & \multirow[b]{2}{*}{$\begin{array}{c}\text { Alkaline } \\
\text { phosphatase } \\
\text { (IU/dL) }\end{array}$} \\
\hline & $\begin{array}{c}\mathrm{Hb} \\
(\mathrm{g} / \mathrm{dL})\end{array}$ & $\begin{array}{l}\text { Hct } \\
(\%)\end{array}$ & $\begin{array}{c}\text { Leukocytes } \\
\left(10^{3 *} \text { Cells } / \mathrm{mL}\right)\end{array}$ & $\begin{array}{c}\text { Cholesterol } \\
\text { (mg/dL) }\end{array}$ & $\begin{array}{l}\mathrm{HDL}(\mathrm{mg} / \\
\mathrm{dL})\end{array}$ & $\begin{array}{c}\text { Tryglicerides } \\
\text { (mg/dL) }\end{array}$ & $\begin{array}{l}\text { Glucosa } \\
\text { (mg/dL) }\end{array}$ & $\begin{array}{l}\text { Urea (IU/ } \\
\text { dL) }\end{array}$ & $\begin{array}{l}\text { Creatinine } \\
\text { (mg/dL) }\end{array}$ & $\begin{array}{c}\text { ALT } \\
(\mathrm{IU} / \mathrm{dL})\end{array}$ & \\
\hline PS & $\begin{array}{c}11.8 \pm \\
0.4\end{array}$ & $37.2 \pm 0.8$ & $7.8 \pm 1.7$ & $115.5 \pm 2.6$ & $39.3 \pm 1.2$ & $94.0 \pm 3.5^{\mathrm{a}}$ & $82.7 \pm 10.4^{b}$ & $\begin{array}{c}18.5 \pm \\
2.1\end{array}$ & $1.0 \pm 0.2^{\mathrm{a}}$ & $18.3 \pm 3.3$ & $8.5 \pm 1.3^{\mathrm{ab}}$ \\
\hline ChS $200 \mathrm{mg} / \mathrm{kg}$ & $\begin{array}{c}11.9 \pm \\
0.8\end{array}$ & $37.2 \pm 3.4$ & $7.5 \pm 1.2$ & $139.4 \pm 11.5$ & $57.6 \pm 3.8^{\mathrm{a}}$ & $103.0 \pm 7.9^{a}$ & $60.2 \pm 1.4^{\mathrm{a}}$ & $\begin{array}{c}20.0 \pm \\
2.7\end{array}$ & $0.8 \pm 0.0^{\mathrm{a}}$ & $10.2 \pm 1.4^{\mathrm{a}}$ & $106.2 \pm 3.0^{\mathrm{a}}$ \\
\hline DMBA & $\begin{array}{c}10.6 \pm \\
0.7\end{array}$ & $32.2 \pm 1.9$ & $10.4 \pm 1.2$ & $148.0 \pm 7.4$ & $30.7 \pm 2.9$ & $164.3 \pm 10.8^{b}$ & $100.0 \pm 3.5^{b}$ & $\begin{array}{c}28.0 \pm \\
3.6\end{array}$ & $99.5 \pm 3.2^{\mathrm{b}}$ & $25.8 \pm 1.9^{b}$ & $27.2 \pm 3.4^{\mathrm{b}}$ \\
\hline $\mathrm{DMBA}+\mathrm{ChS} 50$ & $\begin{array}{c}10.6 \pm \\
0.9\end{array}$ & $33.0 \pm 2.3$ & $6.2 \pm 1.3^{\mathrm{a}}$ & $135.0 \pm 4.3$ & $51.4 \pm 6.3$ & $78.8 \pm 9.9^{a}$ & $67.8 \pm 8.0^{\mathrm{b}}$ & $\begin{array}{c}15.8 \pm \\
2.0\end{array}$ & $86.6 \pm 4.4^{\mathrm{b}}$ & $18.4 \pm 2.6$ & $21.0 \pm 5.2^{\mathrm{b}}$ \\
\hline DMBA + ChS 250 & $\begin{array}{c}11.5 \pm \\
1.1\end{array}$ & $36.6 \pm 3.2$ & $6.3 \pm 0.9^{\mathrm{a}}$ & $126.4 \pm 5.4$ & $50.6 \pm 4.5$ & $79.4 \pm 4.7^{\mathrm{a}}$ & $59.9 \pm 10.6$ & $\begin{array}{c}15.9 \pm \\
0.9\end{array}$ & $84.0 \pm 5.3^{\mathrm{b}}$ & $20.4 \pm 2.7$ & $12.4 \pm 1.0^{\mathrm{b}}$ \\
\hline $\mathrm{DMBA}+\mathrm{ChS} 500$ & $\begin{array}{c}11.6 \pm \\
0.4\end{array}$ & $37.3 \pm 0.9$ & $4.9 \pm 0.6^{\mathrm{a}}$ & $110.5 \pm 9.3$ & $52.5 \pm 5.7$ & $94.8 \pm 3.1^{\mathrm{a}}$ & $59.1 \pm 13.3$ & $\begin{array}{c}19.0 \pm \\
0.6\end{array}$ & $81.0 \pm 6.8^{\mathrm{b}}$ & $16.5 \pm 2.5$ & $23.0 \pm 4.7^{\mathrm{b}}$ \\
\hline
\end{tabular}

Notes: PS: Physiological saline; Hb: hemoglobin; Hct: hematocrit; HDL: High density lipoprotein; ALT: Alanine Aminotransferase. ANOVA, Dunnett `s test a: $p<0.05$ (Compared with DMBA), b: $p<0.05$ (Compared with ChS).

Table 3: Evaluation of tumor masses and micronucleus in rats with breast cancer induced by DMBA.

\begin{tabular}{ccc}
\hline & \multicolumn{2}{c}{ Parameters } \\
\cline { 2 - 3 } Experimental Group & $\begin{array}{c}\text { Tumor mass } \\
(\mathrm{X})\end{array}$ & $\begin{array}{c}\text { Micronucleus } \\
(\%)\end{array}$ \\
\hline PS & $0.0 \pm 00^{\mathrm{a}}$ & $0.0 \pm 0.0^{\mathrm{a}}$ \\
ChS 200mg/kg & $0.0 \pm 0.0^{\mathrm{a}}$ & $0.0 \pm 0.0^{\mathrm{a}}$ \\
DMBA & $2.5 \pm 0.5$ & $6.5 \pm 1.0$ \\
DMBA + ChS 50 & $0.2 \pm 0.4^{\mathrm{a}}$ & $1.4 \pm 0.9^{\mathrm{a}}$ \\
DMBA + ChS 250 & $0.2 \pm 0.4^{\mathrm{a}}$ & $0.6 \pm 1.3^{\mathrm{a}}$ \\
DMBA + ChS 500 & $0.0 \pm 0.0^{\mathrm{a}}$ & $0.5 \pm 0.6^{\mathrm{a}}$ \\
\hline
\end{tabular}

ANOVA, Dunnett` Test ${ }^{a}: p<0.05$ (Compared with DMBA)

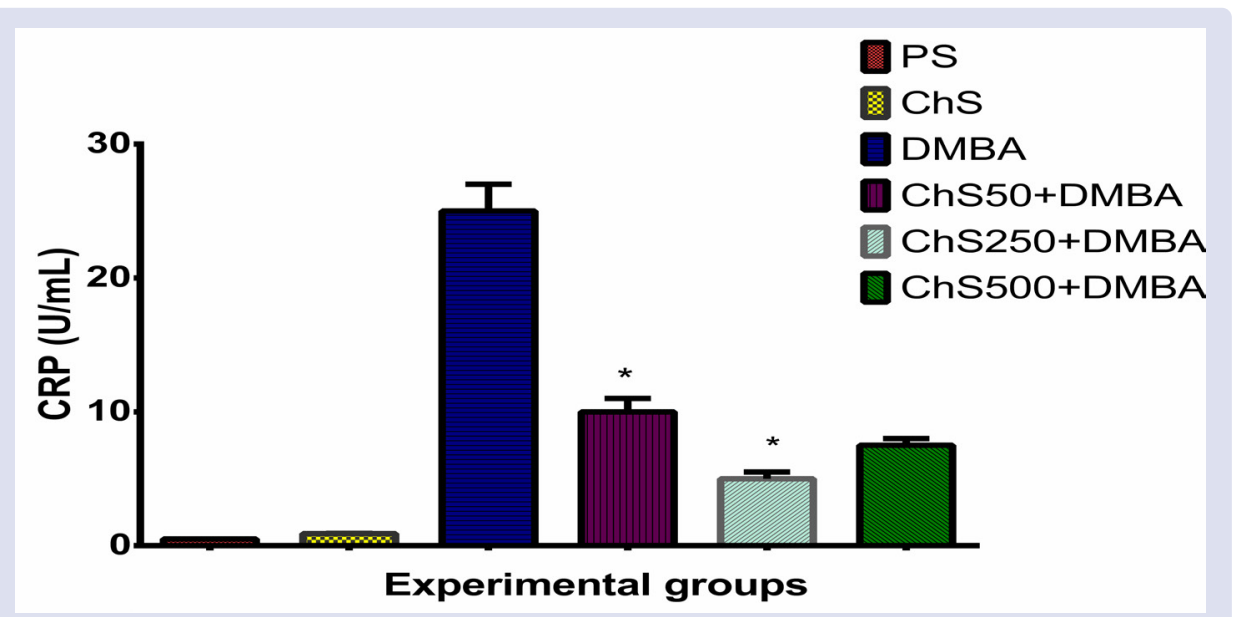

Figure 2: C-Reactive Protein levels in female rats with breast cancer induced with $\mathrm{DMBA} * p<0,05$ Vs DMBA.

The rat mammary glands were observed under the microscope (Figure 4). All groups treated with DMBA presented adenocarcinoma. This coincides with that evaluated in the anatomopathological study, where the presence of intraductal adenocarcinoma is observed in group DMBA. It was observed desmoplastic reactions, metaplasia and cell invasion in the groups treated with Chuquiraga spinosa.

\section{DISCUSSION}

Cancer is the first cause of death in the world. Breast cancer represents the second most common cancer to be diagnosed and incidence in developing countries is progressing. ${ }^{4}$ Inflammation plays an important role in the development of cancer. ${ }^{9}$ DMBA is a polycyclic aromatic hydrocarbon potent that induces DNA damage ${ }^{[14]}$ and cell proliferation in breast tissue. ${ }^{3}$

The ethanolic extract of Chuquiraga spinosa presents various secondary metabolites with high antioxidant activity (Table 1). These results are consistent with those reported by Landa et al. ${ }^{27}$ who detected 9 flavones glycosides ${ }^{28}$ which are associated in retarding cell migration in breast cancer cells by inhibiting P53-ROS ${ }^{29}$ pathway. Its phenolic compounds possess antioxidant activity, by chelation of metals. Their anti-proliferative effect and induction of apoptosis in tumor cells has been observed. ${ }^{4}$ Also, the triterpenes are associated with high antiproliferative activity. ${ }^{30}$ Cancer cells have and increased amount of 
reactive oxygen species and free radicals. ${ }^{31}$ The presence of antioxidants in vivo is a pharmacological target for cancer therapy. ${ }^{32}$ Terpenes are anti-inflammatory compounds, while casearina $\mathrm{G}$ could be more useful for the formulation of antitumor drugs breast and prostate. ${ }^{33}$

Among the associated factors of breast cancer, it is estimated that chronic inflammation triggers the alteration of macrophages. High CRP levels are associated with low survival in patients with breast cancer, ${ }^{34}$ this coincides with our results (Figure 2). ChS reduced CRP levels dose - dependent and showed anti-inflammatory activity. There is growing evidence that obesity is associated with breast cancer in early stages. ${ }^{35}$ Concordantly, we observed the increase in triglycerides, cholesterol and reduced HDL (Table 2) in DMBA group and reduction in the groups treated with ChS. Nevertheless, it is observed an increase in glycemia levels of group DMBA and a potent hypoglycemic effect in ChS 200 (Table 2).

Ch. spinosa extract showed cytotoxic activity in vitro against the MCF-7 tumor cell line, exceeding 5-FU activity (Table 4). However, the cytotoxicity for the 3T3 cell line was minor. It also showed a good security profile by having selectivity rates above unity. Similarly, the degree of dose-effect relationship was significant in all the cell lines.

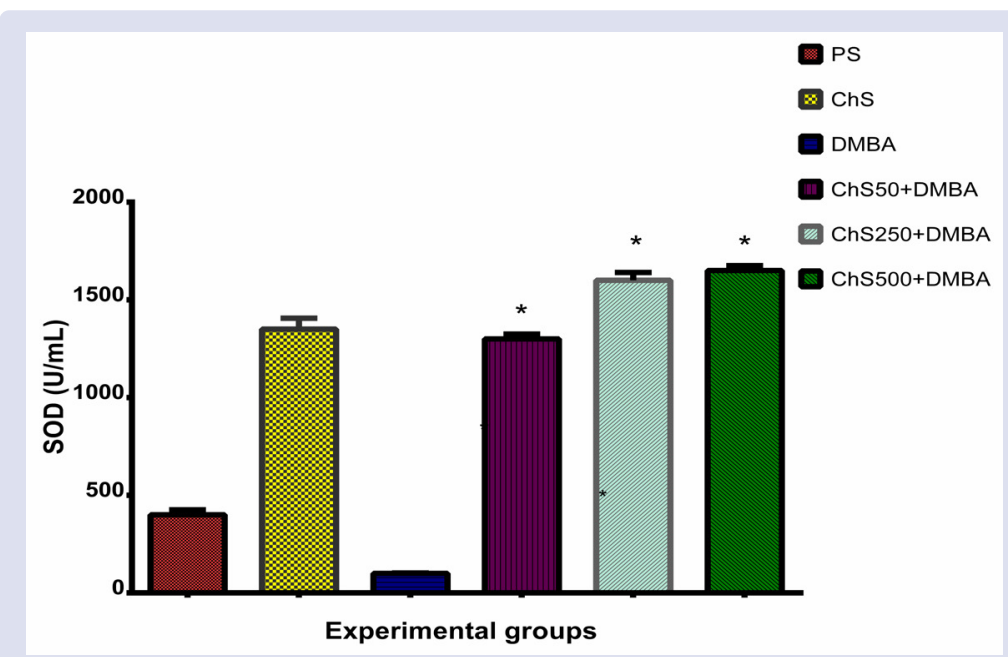

Figure 3: Superoxide dismutase levels in female rats with breast cancer induced with DMBA * $p<0,05$ Vs DMBA.

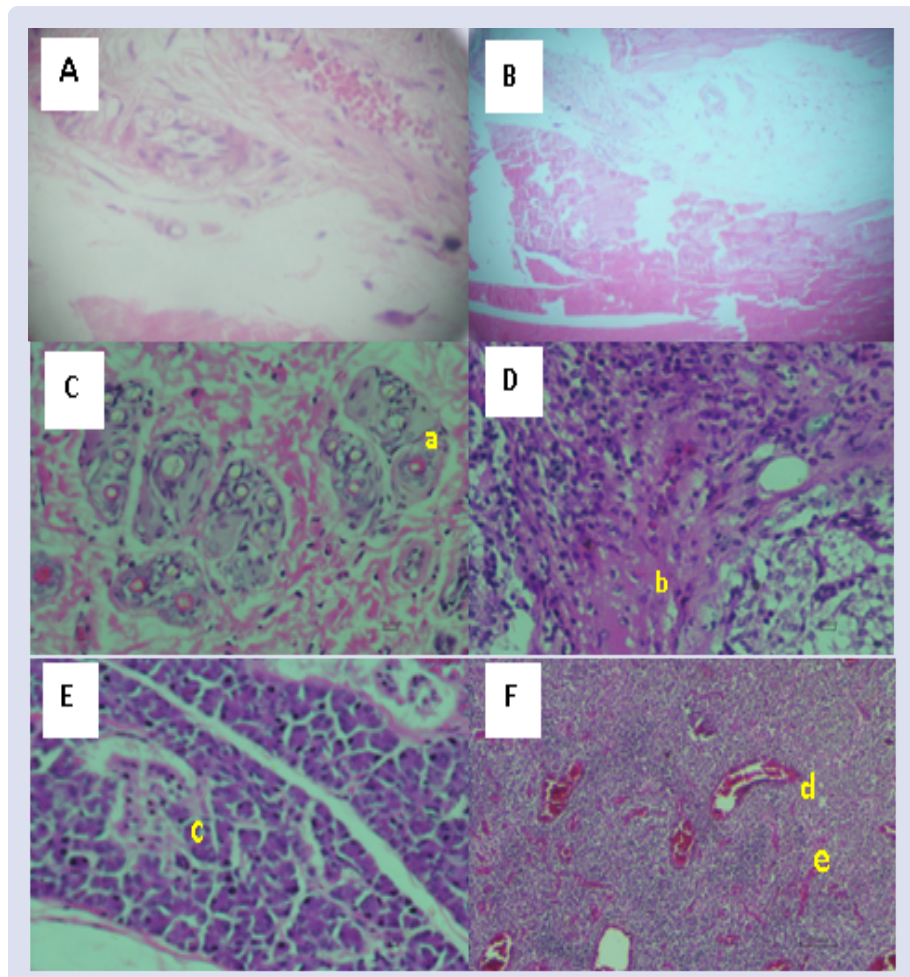

Figure 4: Hematoxylin \& Eosin (H\&E) staining of breast histology in experimental groups. A) Normal Group: Physiological saline, B) ChS 200 $\mathrm{mg} / \mathrm{kg}$; C) DMBA Group; $20 \mathrm{mg} / \mathrm{Kg}$, D) DMBA + ChS $50 \mathrm{mg} / \mathrm{kg}$; E) DMBA + ChS $200 \mathrm{mg} / \mathrm{kg}$; F) DMBA + ChS $500 \mathrm{mg} / \mathrm{Kg}$. a: Intraductal adenocarcinoma, (H\&E) $x 400$; b: desmoplastic reaction (H\&E) x400; c: Metaplasia, (H\&E) x400; d: Congestion (H\&E) x400; e: cell invasion (H\&E) x400. 
Table 4: Cytotoxicity and IC 50 of Chuquiraga spinosa extract and 5-FU in MCF-7 and 3 T3 cell lines.

\begin{tabular}{|c|c|c|c|}
\hline \multirow{2}{*}{ Cytotoxic substances } & \multicolumn{2}{|c|}{$\mathrm{IC}_{50}(\mathrm{ug} / \mathrm{mL})^{*}$} & \multirow{2}{*}{ Selectivity index } \\
\hline & MCF-7 & 3-T3 & \\
\hline Ch. spinosa & $8.53 \pm 0.60$ & $51.4 \pm 0.4$ & 6.02 \\
\hline Control & - & - & - \\
\hline 5-FU & $9.3 \pm 0.9$ & $0.035 \pm 0.01$ & 0.0037 \\
\hline
\end{tabular}

${ }^{*}$ Values are expressed as mean \pm standard deviation. 5-FU, 5-fluorouracil; $\mathrm{IC}_{50}, 50 \%$ inhibitory concentration.

The ethanolic extract of Ch. spinosa presented a selectivity index of 6.02 compared to 0.0037 with 5-FU. Studies with silymarin showed that the alterations in the progression of the cell cycle could be responsible for its anticarcinogenic effect on MCF-7 cells. Resveratrol, a polyphenol, inhibits prostate cancer growth and alters mitogenesis. It achieved significant inhibition of the proliferation of MCF-7. ${ }^{36}$

Thus, the Chuquiraga spinosa triggers reduces breast cancer, possessing powerful antioxidant and anti-inflammatory activity in vivo; As well as the hypoglycemic and lipid-lowering effect. So, the ethanolic extract Chuquiraga spinosa is attributed antitumor effects on DMBA - induced in female rats with breast cancer.

\section{CONCLUSIONS}

From the above results, it can be inferred that Chuquiraga spinosa has high levels of phenolic compounds. Chuquiraga spinosa extract demonstrated antioxidant, antitumorigenic and antigenotoxic properties and we conclude that it can have an ameliorative effect on DMBA-induced breast cancer in rats.

\section{ACKNOWLEDGEMENT}

The authors thank Universidad Nacional Mayor de San Marcos for helping to support this research.

\section{DISCLOSURE STATEMENT}

The authors have no conflicts of interest to declare.

\section{FUNDING SOURCES}

Nil.

\section{REFERENCES}

1. Bagheri SM, Abdian-Asl A, Moghadam MT, Yadegari M, Mirjalili A, ZareMohazabieh $F$, et al. Antitumor effect of Ferula assa foetida oleo gum resin against breast cancer induced by $4 \mathrm{~T} 1$ cells in BALB/c mice. J Ayurveda Integr Med. 2017:8(3):152-8.

2. Figueroa-Montes LE, Chávez-Altamirano NE, García-Espinoza G. Implementación de una unidad de mamovigilancia para el diagnóstico de cáncer de mama en una microred de la seguridad social, Lima-Perú. Acta méd Peru. 2019:36(1):11-8.

3. Joshi S, Kumar S, Ponnusamy MP, Batra SK. Hypoxia-induced oxidative stress promotes MUC4 degradation via autophagy to enhance pancreatic cancer cells survival. Oncogene. 2016;35(45):5882-92.

4. Almora-Pinedo $\mathrm{Y}$, Arroyo-Acevedo J, Herrera-Calderon O, Chumpitaz-Cerrate $\checkmark$, Hañari-Quispe R, Tinco-Jayo A, et al. Preventive effect of Oenothera rosea on N-methyl-N-nitrosourea-(NMU) induced gastric cancer in rats. Clin Exp Gastroenterol. 2017;10:327-32.

5. Sofi MS, Sateesh MK, Bashir M, Ganie MA, Nabi S. Chemopreventive and antibreast cancer activity of compounds isolated from leaves of Abrus precatorius L. 3 Biotech. 2018;8(8):371.

6. Rasouli H, Farzaei MH, Mansouri K, Mohammadzadeh S, Khodarahmi R. Plant Cell Cancer: May Natural Phenolic Compounds Prevent Onset and Development of Plant Cell Malignancy? A Literature Review. Molecules. 2016;21(9):1104.

7. Gray JM, Rasanayagam S, Engel C, Rizzo J. State of the evidence 2017: an update on the connection between breast cancer and the environment. Environ Health. 2017;16(1):94.

8. Rojas-Rojas T, Bourdy G, Ruiz E, Cerapio JP, Pineau P, Gardon J, et al. Herbal Medicine Practices of Patients With Liver Cancer in Peru: A Comprehensive
Study Toward Integrative Cancer Management. Integr Cancer Ther 2018;17(1):52-64

9. Arroyo-Acevedo J, Herrera-Calderón O, Chávez-Asmat R, Anampa-Guzmán A Chumpitaz-Cerrate V, Enciso-Roca E. Protective effect of Chuquiraga spinosa extract on N-methyl-nitrosourea (NMU) induced prostate cancer in rats. Prostate Int. 2017;5(2):47-52.

10. Herrera-Calderon O, Chacaltana-Ramos L, Yuli-Posadas RÁ, Pari-Olarte B, Enciso-Roca E, Tinco-Jayo JA, et al. Antioxidant and Cytoprotective Effect of Piper aduncum L. against Sodium Fluoride (NaF)-Induced Toxicity in Albino Mice. Toxics. 2019;7(2):28.

11. Tafesse TB, Hymete $A$, Mekonnen $Y$, Tadesse $M$. Antidiabetic activity and phytochemical screening of extracts of the leaves of Ajuga remota Benth on alloxan-induced diabetic mice. BMC Complement Altern Med. 2017;17(1):243.

12. Saleh-E-In MM, Sultana N, Hossain MN, Hasan S, Islam MR. Pharmacological effects of the phytochemicals of Anethum sowa L. root extracts. BMC Complement Altern Med. 2016;16(1):464.

13. Zhang YJ, Gan RY, Li S, Zhou Y, Li AN, Xu DP, et al. Antioxidant Phytochemicals for the Prevention and Treatment of Chronic Diseases. Molecules. 2015;20(12):21138-56.

14. Yuliatun L, Amalia S, Rahma AA, Yaumi LA. Electro-Acupuncture Therapy Increases Serum Interferon- $\gamma$ Levels in Rats with 7, 12 Dimethylbenz $(\alpha)$ anthracene (DMBA)-Induced Breast Tumors. Asian Pac J Cancer Prev. 2017;18(5):1323-8.

15. Arroyo-Acevedo J, Chávez-Asmat RJ, Anampa-Guzmán A, Donaires R, RáezGonzáles J. Protective Effect of Piper aduncum Capsule on DMBA-induced Breast Cancer in Rats. Breast Cancer (Auckl). 2015;9:41-8.

16. Hayashi M. The micronucleus test-most widely used in vivo genotoxicity test. Genes Environ. 2016:38:18.

17. Zhong $\mathrm{H}$, Yin $\mathrm{H}$. Role of lipid peroxidation derived 4-hydroxynonenal (4-HNE) in cancer: focusing on mitochondria. Redox Biol. 2015;4:193-9.

18. Andreou AP, Efthymiou M, Yu Y, Watts HR, Noormohamed FH, Ma D, et al Protective effects of non-anticoagulant activated protein $C$ variant (D36A/L38D/ A39V) in a murine model of ischaemic stroke. PLoS One. 2015;10(4):e0122410.

19. Schonewille M, de Boer JF, Mele L, Wolters H, Bloks VW, Wolters JC et al. Statins increase hepatic cholesterol synthesis and stimulate fecal cholesterol elimination in mice. J Lipid Res. 2016;57(8):1455-64.

20. Ajiboye JA, Erukainure OL, Lawal BA, Nwachukwu VA, Tugbobo-Amisu $A O$, Okafor EN. Comparative alteration in atherogenic indices and hypocholesteremic effect of palm oil and palm oil mill effluent in normal albino rats. Heliyon. 2015;1(1):e00010

21. Deori M, Devi D, Kumari S, Hazarika A, Kalita H, Sarma R, et al. Antioxidant Effect of Sericin in Brain and Peripheral Tissues of Oxidative Stress Induced Hypercholesterolemic Rats. Front Pharmacol. 2016;7:319.

22. Mohun AF, Cook IJ. Simple methods for measuring serum levels of the glutamic-oxalacetic and glutamic-pyruvic transaminases in routine laboratories. J Clin Pathol. 1957;10(4):394-9.

23. Talageri VR, Samarth KD, Baxi AJ, Venkataraman PR. Alkaline phosphatase levels in plasma and liver following carbon tetrachloride administration. $\mathrm{Br} J$ Exp Pathol. 1951;32(2):118-23.

24. Liu L, Mo H, Wei S, Raftery D. Quantitative analysis of urea in human urine and serum by $1 \mathrm{H}$ nuclear magnetic resonance. Analyst. 2012;137(3):595-600.

25. Skehan P, Storeng R, Scudiero D, Monks A, McMahon J, Vistica D, et al. New colorimetric cytotoxicity assay for anticancer-drug screening. J Natl Cancer Inst. 1990;82(13):1107-12.

26. Pierozan $P$ Jernerén $F$ Ransome $Y$ Karlsson $O$. The Choice of Euthanasia Method Affects Metabolic Serum Biomarkers. Basic Clin Pharmacol Toxicol. 2017; 121(2):113-8.

27. Landa A, Casado R, Calvo MI. Identification and quantification of flavonoids from Chuquiraga spinosa (Asteraceae). Nat Prod Commun. 2009:4(10):1353-5. 
28. Kapinova A, Kubatka P, Golubnitschaja O, Kello M, Zubor P, Solar P, Pec M. Dietary phytochemicals in breast cancer research: Anticancer effects and potential utility for effective chemoprevention. Environ Health Prev Med. 2018;23(1):36

29. Martinson HA, Lyons TR, Giles ED, Borges VF, Schedin P. Developmental windows of breast cancer risk provide opportunities for targeted chemoprevention. Exp Cell Res. 2013;319(11):1671-8

30. Dandawate PR, Subramaniam D, Jensen RA, Anant S. Targeting cancer stem cells and signaling pathways by phytochemicals: Novel approach for breast cancer therapy. Semin Cancer Biol. 2016;40-41:192-208.

31. Qi W, Sun M, Kong $X$, Li Y, Wang $X$, Lv S, et al. Huaier extract synergizes with tamoxifen to induce autophagy and apoptosis in ER-positive breast cancer cells. Oncotarget. 2016;7(18):26003-15.

32. Apostolova N, Victor VM. Molecular strategies for targeting antioxidants to mitochondria: therapeutic implications. Antioxid Redox Signal. 2015;22(8):686-729.
33. Rojas-Armas J, Arroyo-Acevedo J, Ortiz-Sánchez M, Palomino-Pacheco $M$, Castro-Luna A, Ramos-Cevallos N, et al. Acute and Repeated 28-Day Oral Dose Toxicity Studies of Thymus vulgaris L. Essential Oil in Rats. Toxicol Res. 2019;35(3):225-32

34. Herrera-Calderon O, Santiváñez-Acosta R, Pari-Olarte B, Enciso-Roca E, Campos-Montes VM, Arroyo Acevedo J. Anticonvulsant effect of ethanolic extract of Cyperus articulatus L. leaves on pentylenetetrazol induced seizure in mice. J Tradit Complement Med. 2017;8(1):95-9.

35. Picon-Ruiz M, Morata-Tarifa C, Valle-Goffin JJ, Friedman ER, Slingerland JM Obesity and adverse breast cancer risk and outcome: Mechanistic insights and strategies for intervention. CA Cancer J Clin. 2017;67(5):378-97.

36. Howell A, Anderson AS, Clarke RB, Duffy SW, Evans DG, Garcia-Closas M, et al. Risk determination and prevention of breast cancer. Breast Cancer Res. 2014;16(5):446

\section{GRAPHICAL ABSTRACT}

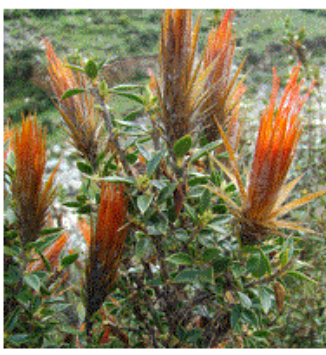

Chuquiraga spinosa aerial parts
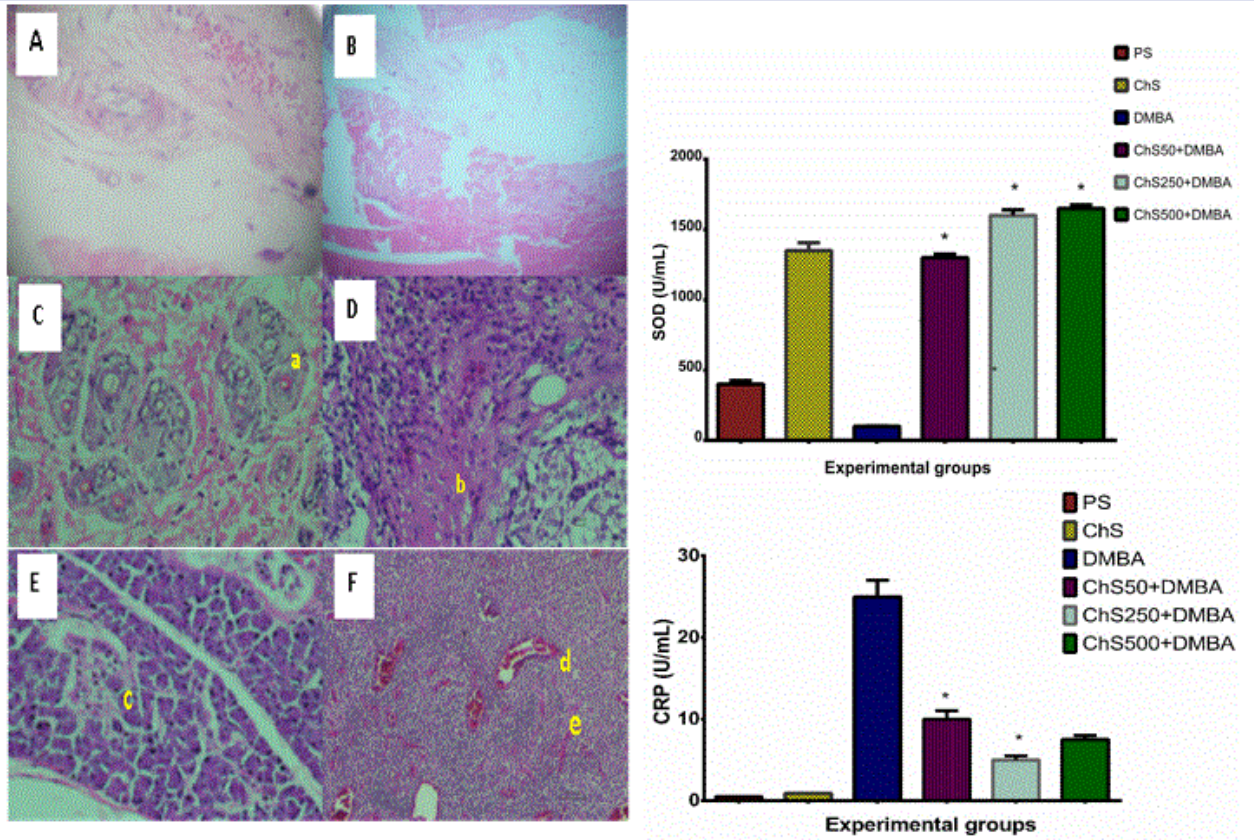

Ameliorative effect of the oral administration of Chuquiraga spinosa in a murine model of breast cancer induced with 7,12Dimethylbenz[a]anthracene (DMBA)

Cite this article: Arroyo-Acevedo J, Herrera-Calderon O, Tinco-Jayo JA, Rojas-Armas JP, Rauf A, Hañari-Quispe R, et al. Ameliorative Effect of the Oral Administration of Chuquiraga Spinosa in a Murine Model of Breast Cancer Induced with 7,12-Dimethylbenz[a] anthracene (DMBA). Pharmacogn J. 2020;12(3):562-8. 